\title{
Prognostic Parameters in Patients with Resected Liver Metastases from Colorectal Cancer after Biological and Chemotherapy
}

\author{
Miljana Džunić1, Ivan Petkovići,2, Ana Cvetanović1,2, Ivica Pejčić1,2, \\ Svetislav Vrbić1,2, Saša Dinić ${ }^{1}$ \\ ${ }^{1}$ Clinic of Oncology, Clinical Center Niš, Niš, Serbia \\ ${ }^{2}$ University of Niš, Faculty of Medicine, Niš, Serbia
}

\begin{abstract}
SUMMARY
The aim of the research was to investigate prognostic factors in patients with resected colorectal liver metastases (CLMs) after biological and chemotherapy, which made initially unresectable disease suitable for resection.

Sixty-six patients with resected CLMs, operated after induction bio-chemotherapy with bevacizumab + FOLFOX4, treated at the Clinic of Oncology, Clinical Center Niš from 2010 - 2017 were included. Disease-free survival (DFS) and overall survival (OS) were estimated using the Kaplan-Meier method and compared using the log-rank test according to demographic characteristics, characteristics of the disease and the treatment. A univariate COX regression analysis was performed.

In patients with up to 4 CLMs, DFS was significantly longer than in patients with five or more metastases $(18,384$ v.s. 6,85 months; $p<0,001)$. Significantly longer OS was present in patients with up to four CLMs than in those with five or more CLMs $(44,687$ v.s. 29,723 months; $p=0,006)$ and in patients without extrahepatic disease $(41,71$ v.s. 23,283 months; $p=0,012)$. In the univariate analysis, five or more CLMs were predictors of poorer DFS (HR 3,989; 95\% CI 1,055 - 15,087; $p=0,042$ ), whereas the absence of extrahepatic disese was a predictor of better OS (HR 0,122; 95\% CI 0,017-0,869; p = 0,036). CLMs.

Results of this research are in concordance with previous larger studies in patients with resected

The number of hepatic and the presence of extrahepatic metastases are prognostic parameters in patients with resected CLM after conversion bio-chemotherapy.
\end{abstract}

Key words: colorectal cancer, liver, metastases, prognosis, surgery

Corresponding author:

Miljana Džunić

e-mail: drmdzunic@gmail.com 


\section{INTRODUCTION}

Colorectal cancer (CRC) represents one of the most frequent and lethal malignant diseases worldwide (1). Metastases to the liver occur in $25-30 \%$ of all patients and in $60 \%$ of stage IV patients due to the portal venous drainage from the large bowel (2).

Surgical treatment of metastatic sights in combination with systemic therapy provides the best possible outcome for patients with colorectal liver metastases (CLMs) (3). Improved surgical techniques allow more extensive liver disease to be completely (R0) resected, with minimal postoperative complications. Modern chemotherapy combined with biological agents, such as anti-VEGF antibodies (bevacizumab) or anti-EGFR antibodies (cetuximab and panitumumab), induces high response rates, aiming to convert the initially unresectable to resectable disease. Multidisciplinary approach have enabled 5 and 10-year survival of $33 \%$ and $23 \%$, respectively, for initially unresectable liver metastases, after response to conversion chemotherapy and subsequent surgical treatment (4). On the other hand, high recurrence rate, estimated to be $60-80 \%$, and about $10-15 \%$ of early recurrences, questions the utility of invasive treatment and suggests the need for better patient selection. Moreover, the role of surgery in modulation of the host immunity and promotion of tumor spread, although still poorly understood, might be important, especially in more advanced disease setting $(5,6)$.

The purpose of this research was to investigate prognostic factors in patients with resected CLM after conversion bio-chemotherapy bevacizumab +FOLFOX4 (FOLFOX-bev), which made liver metastatic disease suitable for resection.

\section{PATIENTS AND METHODS}

Sixty-six patients with resected CLM, which were upfront not suitable for resection, but operated after induction biologiocal and chemotherapy with FOLFOX-bev, treated at the Clinic of Oncology, Clinical Center Niš from 2010 - 2017, were included. All patients were $\geq 18$ years old, with Eastern Cooperative Oncology Group (ECOG) performance status 0 - 1, had histologically verified colorectal adenocarcinoma and contrast enhanced MSCT-detected unresectable liver metastases. The criteria for CLM unresectability were: $<30 \%$ estimated residual liver volume, metastases in contact with major vessels or not possible initial R0/R1 resection of all hepatic lesions. Metastases present outside the liver had to be resectable or already resected (ovary, lungs, small bowel, omentum and peritoneum). The study was reviewed and approved by the Ethical Committee of Clinical Center Niš.

All patients firstly recieved bio-chemotherapy FOLFOX4-bev (bevacizumab $5 \mathrm{mg} / \mathrm{kg}$ and oxaliplatin $85 \mathrm{mg} / \mathrm{m}^{2}$ on day 1 , leucovorin $200 \mathrm{mg} / \mathrm{m}^{2}, 5-\mathrm{FU} 400$ $\mathrm{mg} / \mathrm{m}^{2}$ bolus and $600 \mathrm{mg} / \mathrm{m}^{2}$ 22-hour continuous intravenous infusion on days 1 and 2; repeated every 2 weeks). Response evaluation and resectability were assessed using contrast enhanced MSCT scan every three months. Response was evaluated as complete response $(\mathrm{CR})$, partial response $(\mathrm{PR})$, stable disease (SD) or progressive disease (PD), according to Response Evaluation Criteria in Solid Tumors (RECIST) v. 1.1. If metastases became resectable, patients were operated at 6 weeks after the last chemotherapy. Patients were closely followed (clinical examination, laboratory analyses, tumor marker CEA and abdominal echosonography every three months and contrast-enhanced MSCT scan was done postoperatively (at least four weeks after hepatecomy) and every six months afterwards. Upon progression, patients were treated with available systemic and loco-regional procedures, where appropriate.

Data about age, gender, primary tumor localization, number of liver metastases, synchronous (at diagnosis or within three months from the surgery of primary tumor) or metachronous (after 3 months from the surgery of primary tumor) liver involvement, number of FOLFOX-bev chemotherapy cycles, response to chemotherapy, KRAS status, disease-free survival (DFS) - time from liver surgery to documented disease progression/death in months, and overall survival (OS) - time from CLM diagnosis to death in months was collected.

Comparison of DFS and OS according to age, gender, primary tumor localization, timing of liver metastases, number of liver metastases, presence of extrahepatic disease, number of preoperative biochemotherapy cycles, treatment response, postoperative chemotherapy and KRAS status was done. Statistical analysis was performed using SPSS statistical software, version 25.0 for Windows. Descriptive statistics was used for qualitative and quantitative assessment of the results: absolute numbers, relative numbers $(\%)$, mean value $(\bar{X})$, standard deviation (SD), and median value. DFI and OS were estimated 
using the Kaplan-Meier method, and compared using the log-rank test. Univariate COX regression analysis was performed. $P$ values of $<0.05$ were considered statistically significant.

\section{RESULTS}

From the total number of 66 patients, 49 $(74,2 \%)$ were men and $17(25,8 \%)$ were women. Primary tumor was located in the right colon in 14 patients $(21,2 \%)$ and 52 patients $(78,8 \%)$ had primary tumor in the left colon or rectum. Synchronous metastatic disease was found in 42 patients $(63,6 \%)$, and metachronous disease had 24 patients $(36,4 \%)$. Liver limited disease was present in 58 patients $(87,9 \%)$.

The average number of preoperative biochemotherapy cycles was $6,03 \pm 2,112$, the minimum being 3 and maximum 10 cycles. Seventy-two point seven percent of patients received up to 5 cycles of bio-chemiotherapy, while 27,3\% (18) received 6 - 10 cycles. A total number of patients with objective res- ponse (CR+PR) was $24(63,6 \%)$, and SD (without objective response) was present in 24 patients $(36,4 \%)$. Twenty-six $(39,4 \%)$ patients received postoperative chemotherapy. KRAS status was assessed in 37,9\% of patients, being wild type in 14 patients and mutated in 11 patients. The median follow-up was 29,5 months (range $11-88$ ).

\section{Disease-free survival}

Mean DFS was 12,32 (95\% CI 9,08 - 15,56) months. In patients with up to 4 hepatic metastases, DFS was significantly longer than in patients with 5 or more metastases (18,384 v.s. 6,85 months; $\mathrm{p}<$ 0,001) (Table 1, Figure 1).

There was no statistically significant difference in DFS according to gender (men v.s. women; $p$ $=0,956$ ), age (under 60 v.s. 60 and older; $p=0,116$ ), localization of primary tumor (right v.s.left colon and rectum; $p=0,594$ ), appearance of hepatic metastases (synchronous v.s. metachronous; $p=0,073$ ) and presence of extrahepatic metastases $(p=0,751)$. DFS

Table 1. Disease-free survival according to the studied parameters

\begin{tabular}{|c|c|c|c|c|c|c|}
\hline Parameter & & $\begin{array}{l}\text { Mean } \\
\text { DFS }\end{array}$ & SE & $95 \% \mathrm{CI}$ & $\begin{array}{l}\text { Log Rank } \\
\text { test }\end{array}$ & $\mathrm{P}$ \\
\hline \multirow{2}{*}{ Gender } & Men & 15,109 & 2,866 & $9,492-20,726$ & \multirow{2}{*}{0,003} & \multirow{2}{*}{0,956} \\
\hline & Women & 13,914 & 3,917 & $6,236-21,592$ & & \\
\hline \multirow{2}{*}{ Age } & Under 60 & 12,859 & 4,304 & $4,423-21,295$ & \multirow{2}{*}{2,477} & \multirow{2}{*}{0,116} \\
\hline & 60 and older & 15,863 & 2,236 & $11,481-20,244$ & & \\
\hline \multirow{2}{*}{$\begin{array}{l}\text { Localization of primary } \\
\text { tumor }\end{array}$} & Right colon & 11,971 & 3,118 & $5,860-18,083$ & \multirow{2}{*}{0,285} & \multirow{2}{*}{0,594} \\
\hline & Left colon + rectum & 15,910 & 2,858 & $10,309-21,511$ & & \\
\hline \multirow{2}{*}{ Number of hepatic metastases } & $1-4$ & 18,384 & 3,098 & $12,312-24,456$ & \multirow{2}{*}{14,473} & \multirow[t]{2}{*}{$<0,001$} \\
\hline & $\geq 5$ & 6,850 & 1,820 & $3,284-10,416$ & & \\
\hline \multirow{2}{*}{$\begin{array}{l}\text { Appearance of } \\
\text { hepatic metastases }\end{array}$} & Synchronous & 12,966 & 2,931 & $7,222-18,709$ & \multirow{2}{*}{3,211} & \multirow[t]{2}{*}{0,073} \\
\hline & Metachronous & 16,921 & 2,419 & $12,180-21,662$ & & \\
\hline \multirow{2}{*}{ Extrahepatic metastases } & Yes & 9,750 & 2,314 & $5,215-14,285$ & \multirow{2}{*}{0,101} & \multirow[t]{2}{*}{0,751} \\
\hline & No & 15,198 & 2,483 & $10,332-20,064$ & & \\
\hline \multirow{2}{*}{ Preoperative chemotherapy } & Up to 5 cycles & 14,489 & 1,923 & $10,721-18,258$ & \multirow{2}{*}{0,748} & \multirow[t]{2}{*}{0,387} \\
\hline & $6-10$ cycles & 14,056 & 5,319 & $3,631-24,480$ & & \\
\hline \multirow{2}{*}{ Objective response to therapy } & Yes (CR+PR) & 16,842 & 3,078 & $10,809-22,875$ & \multirow{2}{*}{2,305} & \multirow[t]{2}{*}{0,129} \\
\hline & No (SD) & 10,125 & 2,193 & $5,826-14,424$ & & \\
\hline \multirow{2}{*}{ Postoperative chemotherapy } & Yes & 13,863 & 1,888 & $10,163-17,563$ & \multirow{2}{*}{0,181} & \multirow{2}{*}{0,670} \\
\hline & No & 15,253 & 3,467 & $8,456-22,049$ & & \\
\hline \multirow{2}{*}{ KRAS status } & WT & 6,214 & 1,618 & $3,043-9,385$ & \multirow{2}{*}{0,669} & \multirow{2}{*}{0,413} \\
\hline & Mutated & 7,364 & 1,337 & 4,744- 9,984 & & \\
\hline
\end{tabular}

SE-standard error 


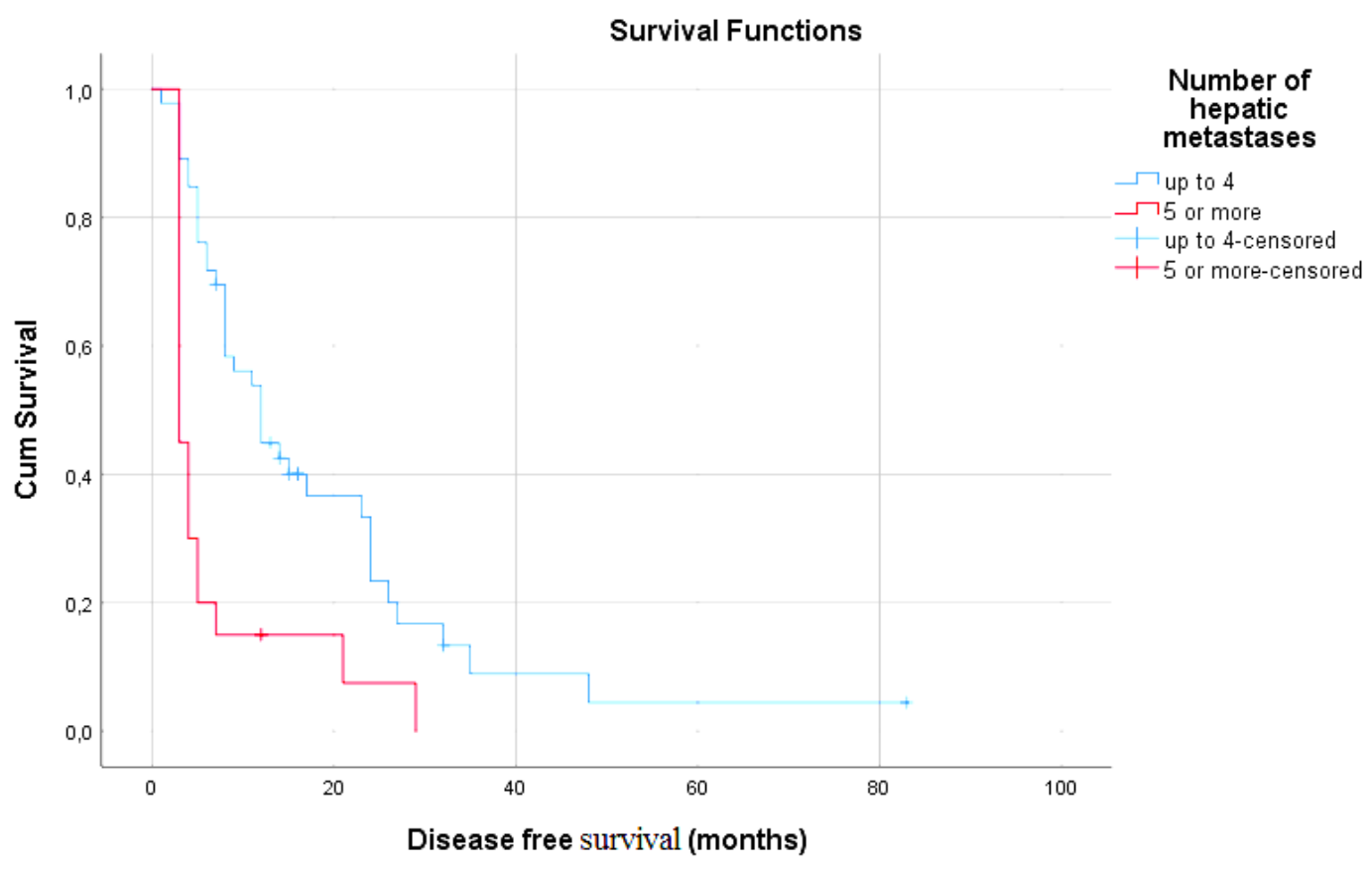

Figure 1. Kaplan-Meier curves of DFS according to the number of hepatic metastases. In patients with up to 4 hepatic metastases, DFS was significantly longer than in patients with 5 of more metastases $(18,384$ v.s. 6,85 months; $p<0,001)$

Table 2. Overall survival according to the studied parameters

\begin{tabular}{|c|c|c|c|c|c|c|}
\hline \multicolumn{2}{|c|}{ Parameter } & \multirow{2}{*}{$\begin{array}{l}\text { Mean } \\
\text { OS } \\
39,466\end{array}$} & \multirow{2}{*}{$\begin{array}{l}\text { SE } \\
3,240 \\
\end{array}$} & \multirow{2}{*}{$\begin{array}{l}95 \% \text { CI } \\
33,116-45,817\end{array}$} & \multirow{3}{*}{ 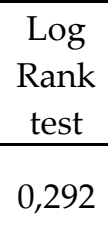 } & \multirow{3}{*}{$\begin{array}{c}\mathrm{P} \\
0,589\end{array}$} \\
\hline \multirow{2}{*}{ Gender } & Men & & & & & \\
\hline & Women & 45,591 & 7,168 & $31,542-59,639$ & & \\
\hline \multirow{2}{*}{ Age } & Under 60 & 40,557 & 6,721 & $27,383-53,731$ & \multirow{2}{*}{0,580} & \multirow{2}{*}{0,446} \\
\hline & 60 and older & 40,393 & 2,477 & $35,537-45,249$ & & \\
\hline \multirow{2}{*}{$\begin{array}{l}\text { Localization of primary } \\
\text { tumor }\end{array}$} & Right colon & 32,092 & 2,850 & $26,506-37,677$ & \multirow{2}{*}{2,358} & \multirow{2}{*}{0,125} \\
\hline & Left colon + rectum & 42,287 & 3,520 & $35,389-49,186$ & & \\
\hline \multirow{2}{*}{$\begin{array}{l}\text { Number of } \\
\text { hepatic metastases }\end{array}$} & $1-4$ & 44,687 & 3,698 & $37,438-51,936$ & \multirow{2}{*}{7,699} & \multirow{2}{*}{0,006} \\
\hline & $\geq 5$ & 29,723 & 2,490 & $24,842-34,604$ & & \\
\hline \multirow{2}{*}{$\begin{array}{l}\text { Appearance of hepatic } \\
\text { metastases }\end{array}$} & Synchronous & 38,748 & 3,815 & $31,271-46,226$ & \multirow{2}{*}{1,150} & \multirow{2}{*}{0,284} \\
\hline & Metachronous & 44,200 & 5,008 & $34,384-54,017$ & & \\
\hline \multirow{2}{*}{ Extrahepatic metastases } & Yes & 23,283 & 1,562 & $20,221-26,345$ & \multirow{2}{*}{6,283} & \multirow{2}{*}{0,012} \\
\hline & No & 41,710 & 3,151 & $35,534-47,887$ & & \\
\hline \multirow{2}{*}{$\begin{array}{l}\text { Preoperative } \\
\text { chemotherapy }\end{array}$} & Up to 5 cycles & 38,400 & 2,804 & $32,904-43,896$ & \multirow{2}{*}{0,059} & \multirow{2}{*}{0,808} \\
\hline & 6-10 cycles & 41,954 & 5,345 & $31,477-52,431$ & & \\
\hline \multirow{2}{*}{$\begin{array}{l}\text { Objective response to } \\
\text { therapy }\end{array}$} & Yes (CR+PR) & 43,029 & 4,546 & $34,120-51,939$ & \multirow{2}{*}{0,363} & \multirow{2}{*}{0,547} \\
\hline & No (SD) & 36,779 & 2,575 & $31,732-41,826$ & & \\
\hline \multirow{2}{*}{$\begin{array}{l}\text { Postoperative } \\
\text { chemotherapy }\end{array}$} & Yes & 38,743 & 3,024 & $32,815-44,671$ & \multirow{2}{*}{0,024} & \multirow{2}{*}{0,877} \\
\hline & $\mathrm{No}$ & 41,537 & 4,420 & $32,875-50,200$ & & \\
\hline \multirow{2}{*}{ KRAS status } & WT & 35,532 & 4,410 & $26,887-44,176$ & \multirow{2}{*}{1,312} & \multirow{2}{*}{0,252} \\
\hline & Mutated & 30,131 & 2,560 & $25,114-35,149$ & & \\
\hline
\end{tabular}

SE-standard error 


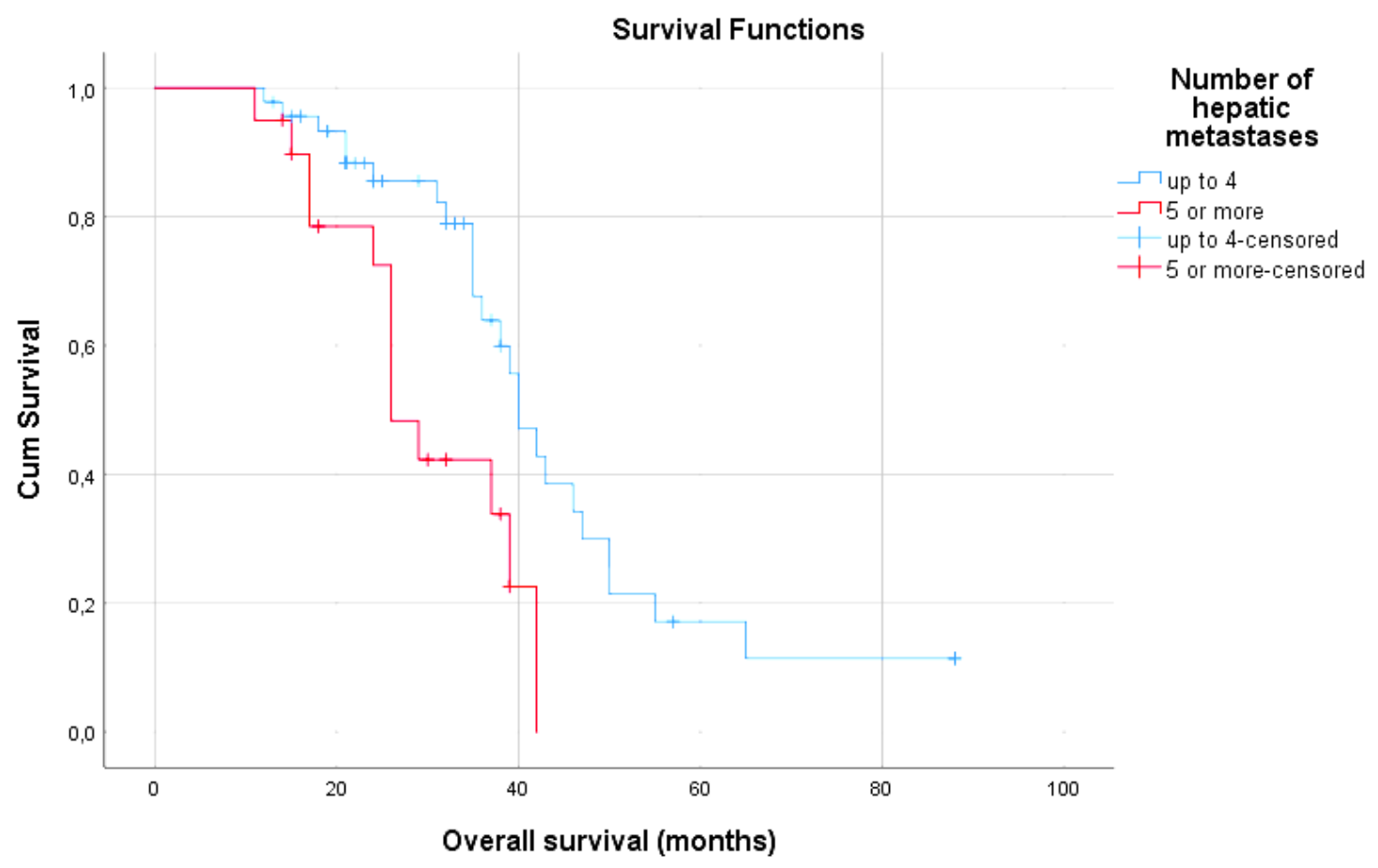

Figure 2. Kaplan-Meier curves of OS according to number of hepatic metastases. Patients with up to 4 hepatic metastases had significantly longer OS than patients with 5 or more lesions $(44,687$ v.s. 29,723 months; $p=0,006)$

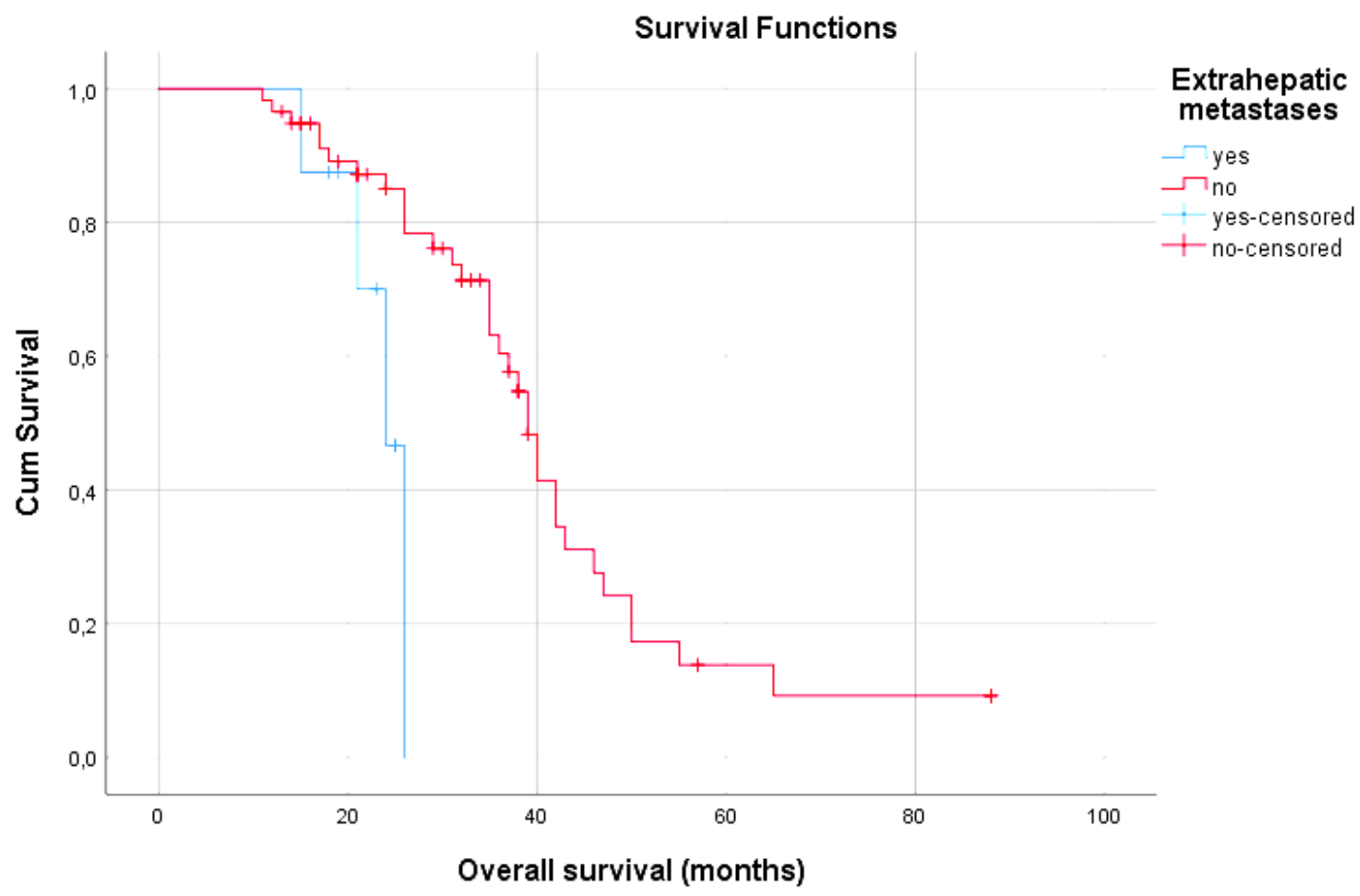

Figure 3. Kaplan-Meier curves of OS according to the presence of extrahepatic metastases. Patients without extrahepatic metastases had significantly better OS (41,71 v.s. 23,283 months; $p=0,012)$ 
Table 3. Cox regression analysis of DFS and OS

\begin{tabular}{l|l|l|l|l|l|l}
\hline \hline \multirow{2}{*}{ Parameter } & \multicolumn{4}{|c|}{ DFS } & \multicolumn{3}{c}{ OS } \\
\cline { 2 - 8 } & HR & $95 \%$ CI & p & HR & $95 \%$ CI & $p$ \\
\hline Gender & 0,944 & $0,206-4,32$ & 0,941 & 0,238 & $0,027-2,120$ & 0,198 \\
\hline Age & 1,148 & $0,408-3,228$ & 0,794 & 0,939 & $0,874-1,009$ & 0,087 \\
\hline Localization of primary tumor & 0,928 & $0,274-3,137$ & 0,904 & 1,123 & $0,286-4,414$ & 0,868 \\
\hline Number of hepatic metastases & 3,989 & $1,055-15,087$ & 0,042 & 3,321 & $0,801-13,767$ & 0,098 \\
\hline Appearance of hepatic metastases & 1,666 & $0,421-6,586$ & 0,467 & 2,453 & $0,354-16,992$ & 0,363 \\
\hline Extrahepatic metastases & 1,258 & $0.336-4,710$ & 0,733 & 0,122 & $0,017-0,869$ & 0,036 \\
\hline Preoperative chemotherapy & 2,476 & $0,661-9,278$ & 0,179 & 0,775 & $0,560-1,073$ & 0,125 \\
\hline Objective response to therapy & 1,281 & $0,356-4,608$ & 0,705 & 3,378 & $0,628-18,182$ & 0,156 \\
\hline Postoperative chemotherapy & 2,891 & $0,862-9,689$ & 0,085 & 0,707 & $0,193-2,590$ & 0,601 \\
\hline KRAS status & 0,774 & $0,292-2,053$ & 0,607 & 1,732 & $0,502-5,973$ & 0,385 \\
\hline \hline
\end{tabular}

was not significantly different according to the number of preoperative chemotherapy cycles received (up to 5 v.s. 6 - 10 cycles; $p=0,387$ ), presence of objective response to chemotherapy $(\mathrm{p}=$ $0,129)$, application of postoperative chemotherapy ( $\mathrm{p}$ $=0,67)$ or KRAS status $(\mathrm{p}=0,413)$ (Table 1$)$.

\section{Overall survival}

Mean OS was 32,54 months (95\% CI 28,25 $36,83)$. Significantly longer OS was present in patients with up to 4 hepatic metastases than in those with 5 or more liver lesions (44,687 v.s. 29,723 months; $p=0,006$ ) (Table 2, Figure 2). Patients without extrahepatic metastatic disease had significantly better OS (41,71 v.s. 23,283 months; $\mathrm{p}=0,012$ ) (Table 2, Figure 3).

There was no statistically significant difference in OS according to gender $(p=0,589)$, age $(p=$ $0,446)$, localization of primary tumor $(p=0,125)$ and appearance of hepatic metastases $(p=0,284)$. Significant OS difference was not present according to the number of received preoperative chemotherapy cycles $(p=0,808)$, objective response to therapy $(p=$ 0,547 ), application of postoperative chemotherapy ( $p$ $=0,877)$ or KRAS status $(p=0,252)$ (Table 2$)$.

\section{Univariate analysis}

In the univariate analysis (Cox regression), 5 or more hepatic metastases were predictive for poorer DFS (HR 3,989; 95\% CI 1,055 - 15,087; p = $0,042)$ and the absence of extrahepatic disease was predictive for better OS (HR 0,122; 95\% CI 0,017 0,869; $\mathrm{p}=0,036$ ) (Table 3).

\section{DISCUSSION}

Although metastatic disease has been traditionally reserved for systemic treatment options, the surgery became the cornerstone of the CLMs treatment, providing excellent survival rates and the possibility of cure. However, about $80 \%$ of patients initially present with unresectable liver involvement require chemotherapy combined with biological agents as the most effective treatment in order to downsize CLMs and enable operation $(4,7)$. In spite of the fact that the survival rates of patients that are operated after conversion therapy are lower than in those with initially resectable CLMs, they are much better than in patients treated with systemic agents only (3). Therefore, multidisciplinary approach is the best strategy.

According to European Society of Medical Oncology (ESMO) consensus guideline from 2016, the assessment of resectability is an essential step in tailoring CLMs treatment, and specific technical as well as oncological criteria should be considered in deciding about hepatic resection. In that way, concomitant unresectable extrahepatic disease, five and more hepatic lesions and tumor progression on systemic treatment stand for oncological contraindications for hepatic resection (3). These parameters have shown to be strong predictors of shorter DFS and OS in numerous retrospective analyses $(8-10)$. Results of our study are in concordance with previ- 
ous studies. Patients with five or more hepatic metastases had significantly worse DFS (18,384 v.s. $6,85$ months; $\mathrm{p}<0,001)$ and OS (44,687 v.s. 29,723 months; $\mathrm{p}=0,006)$ and five or more hepatic metastases were prognostic for poorer DFS (HR3,989; 95\% CI 1,055 - 15,087; p =0,042). Patients without extrahepatic disease had significantly better OS (41,71 v.s. 23,283 months; $p=0,012$ ) and the absence of extrahepatic disease was a prognostic factor for better OS (HR 0,122; 95\% CI 0,017 - 0,869; p = 0,036).

Demographic factors, such as gender and age, are commonly tested as prognostic factors in clinical studies. While gender showed to have no importance, age could have some prognostic implications in metastatic CRC (11). It has been shown that the youngest and the oldest patients have worse prognosis $(12,13)$. The study in young patients with resected CLMs identified that very young patients have significantly worse PFS and tend to have worse survival than elderly (14). However, in our study, which included patients with resected CLMs after conversion treatment, significant difference in DFS and OS between patients older than 60 years and younger were not detected.

Patients with metachronous metastases have been considered to have better prognosis than those with synchronous metastatic disease $(10,15)$. However, in our and several other studies $(16,17)$, the time to CLMs appearance did not have prognostic importance. Although it is known that patients with left colon cancer have better prognosis (18), our results did not show difference in DFS and OS according to the primary tumor localization. The prognostic role was not confirmed for the KRAS mutational status as well, albeit it is believed that patients with metastatic CRC with KRAS mutations have worse prognosis (19).

All these factors are surrogates for the tumor biology, proved to be of prognostic importance in patients with metastatic CRC that have been treated mainly solely with systemic agents. In our study, all patients were surgically treated after systemic treatment. It is possible that surgery may diminish the effect of tumor biology, due to excessive tumor burden reduction. However, we could not neglect the small sample size of this study that might be the reason for the negative results of the studied parameters.

Considering that all patients had been converted to resectable after systemic treatment, all of them had positive response to bio-chemotherapy to some extent. Still, the number of preoperative chemotherapy cycles, objective response to systemic treatment and the application of postoperative chemotherapy have not proved to be of prognostic significance for the operated patients. It seems that in this specific patient subgroup, the main role of systemic treatment is to enable resection.

\section{CONCLUSION}

The factors of prognostic significance in patients with CLMs operated after conversion chemotherapy in combination with bevacizumab are the number of hepatic metastases and the presence of extrahepatic disease. Patients with multiple liver metastases and extrahepatic involvement have significantly worse OS. This study emphasizes the tumor burden as the major prognostic factor in this patient subgroup. 


\section{References}

1. Bray F, Ferlay J, Soerjomataram I, et al. Global Cancer Statistics 2018: GLOBOCAN Estimates of Incidence and Mortality Worldwide for 36 Cancers in 185 Countries. CA Cancer J Clin 2018; 68(6): 394-424. Available at:

https://doi.org/10.3322/caac.21492.

2. Engstrand J, Nilsson $\mathrm{H}$, Strömberg C, et al. Colorectal cancer liver metastases - a populationbased study on incidence, management and survival. BMC Cancer 2018; 18(1): 78. Available at: https://doi.org/10.1186/s12885-017-3925-x.

3. Van Cutsem E, Cervantes A, Adam R, et al. ESMO consensus guidelines for the management of patients with metastatic colorectal cancer. Ann Oncol 2016; 27(8): 1386-422. Available at: https://doi.org/10.1093/annonc/mdw235.

4. Adam R, Delvart V, Pascal G, et al. Rescue surgery for unresectable colorectal liver metastases downstaged by chemotherapy: a model to predict long-term survival. Ann Surg2004; 240: 64457. discussion 657-8. Available at: https://doi.org/10.1097/01.sla.0000141198.92114.f6.

5. Neeman E and Ben-Eliyahu S. Surgery and stress promote cancer metastasis: new outlooks on perioperative mediating mechanisms and immune involvement. Brain Behav Immun 2013; 30: S32-40. Available at: https://doi.org/10.1016/j.bbi.2012.03.006.

6. Horowitz M, Neeman E, Sharon E, and BenEliyahu S. Exploiting the critical perioperative period to improve longterm cancer outcomes. Nature Rev Clin Oncol 2015; 12(4): 213-26. Available at:

https://doi.org/10.1038/nrclinonc.2014.224.

7. Imai $\mathrm{K}$, Adam $\mathrm{R}$, Baba $\mathrm{H}$. How to increase the resectability of initially unresectable colorectal liver metastases: A surgical perspective. Ann Gastroenterol Surg 2019; 3(5): 476-86. Available at: https://doi.org/10.1002/ags3.12276.

8. Fong Y, Fortner J, Sun RL et al. Clinical score for predicting recurrence after hepatic resection for metastatic colorectal cancer: analysis of 1001 consecutive cases. Ann Surg 1999; 230: 309-318; discussion 318-321. Available at: https://doi.org/10.1097/00000658-199909000-00004.

9. Scheele J, Stangl R, Altendorf-Hofmann A. Hepatic metastases from colorectal carcinoma: impact of surgical resection on the natural history. Br J Surg 1990; 77: 1241-6. Available at: https://doi.org/10.1002/bjs.1800771115

10. Minagawa M, Makuuchi M, Torzilli G, et al. Extension of the frontiers of surgical indications in the treatment of liver metastases from colorectal cancer: long-term results of our experience. Ann Surg 2000; 23: 487-99. Available at: https://doi.org/10.1097/00000658-200004000-00006

11. Donadon M, Lleo A, Di Tommaso L, et al. The Shifting Paradigm of Prognostic Factors of Colorectal Liver Metastases: From Tumor Centered to Host Immune-Centered Factors. Front Oncol 2018; 8: 181. Available at: https://doi.org/10.3389/fonc.2018.00181.

12. Lieu $\mathrm{CH}$, Renfro LA, de Gramont $\mathrm{A}$ et al. Association of age with survival in patients with metastatic colorectal cancer: analysis from the ARCAD Clinical Trials Program. J Clin Oncol 2014; 32: 2975-84. Available at: https://doi.org/10.1200//CO.2013.54.9329

13. Dzunic M, Andjelkovic-Apostolovic M, Vrbic S et al. Survival of patients with liver metastases from colorectal cancer treated with bevacizumab and FOLOFOX4. J BUON 2020; 25(1): 212-19. 
14. de Haas RJ, Wicherts DA, Salloum C et al. Long term outcomes after hepatic resection for colorectal metastases in young patients. Cancer 2010; 116: 647-58. Available at:

https://doi.org/10.1002/cncr.24721.

15. Baldessari C, Spallanzani A, Gelsomino F, et al. Outcome and prognostic factors after resection of liver metastases in patients with colorectal cancer. Ann Oncol 2017; 28(6): vi13-vi14. Available at: https://doi.org/10.1093/annonc/mdx422.036

16. Taylor M, Forster J, Langer B, et al. A study of prognostic factors for hepatic resection for colorectal metastases. Am J Surg 1997; 173: 467-71. Available at: https://doi.org/10.1016/S0002-9610(97)00020-2
17. Doci R, Gennari L, Bignami P, et al. One hundred patients with hepatic metastases from colorectal cancer treated by resection: analysis of prognostic determinants. Br J Surg 1991; 78: 797-801. Available at:

https://doi.org/10.1002/bjs.1800780711

18. Wang Z, Wang $X$, Zhang Z, et al. Association between Primary Tumor Location and Prognostic Survival in Synchronous Colorectal Liver Metastases after Surgical Treatment: A Retrospective Analysis of SEER Data. J Cancer 2019; 10(7): 1593-1600. Available at: https://doi.org/10.7150/jca.29294

19. Dzunic M, Petkovic I, Cvetanovic A, et al. Current and future targets and therapies in metastatic colorectal cancer. J BUON 2019; 24(5): 1785-92. 


\title{
Prognostički parametri kod bolesnika operisanih od metastaza kolorektalnog karcinoma u jetri nakon biološke terapije $\mathrm{i}$ hemioterapije
}

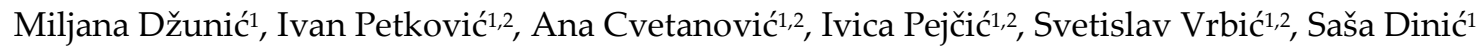 \\ ${ }^{1}$ Klinika za onkologiju, Klinički centar Niš, Niš, Srbija \\ ${ }^{2}$ Univerzitet u Nišu, Medicinski fakultet, Niš, Srbija
}

\section{S A ŽETAK}

Cilj rada bio je utvrditi prognostičke parametre kod bolesnika sa metastazama kolorektalnog karcinoma $u$ jetri (CLM), operisanih nakon biološke terapije i hemioterapije, koje su dovele do resektabilnosti inicijalno neresektabilnih metastaza.

U studiju je uključeno šezdeset šest bolesnika sa operativno lečenim CLM, nakon primljene indukcione bio-hemioterapije bevacizumab + FOLFOX4, lečenih na Klinici za onkologiju Kliničkog centra Niš, u periodu od 2010. do 2017. godine. Preživljavanje bez bolesti (DFS) i ukupno preživljavanje (OS) procenjeni su korišćenjem Kaplan-Majer metode $\mathrm{i}$ poređeni korišćenjem log-rank testa, prema demografskim karakteristikama, karakteristikama bolesti i tretmana. Univarijantna COX regresiona analiza takođe je rađena.

DFS je bilo značajno duže kod bolesnika sa do 4 CLM u odnosu na one sa 5 ili više CLM $(18,384$ meseca naspram 6,85 meseci; $p<0,001$ ). Značajno duže OS bilo je prisutno kod bolesnika sa do 4 CLM, nego kod onih sa 5 ili više CLM $(44,687$ meseci naspram 29,723 meseca; $p=0,006)$ kao i kod bolesnika bez ekstrahepatične bolesti $(41,71$ mesec naspram 23,283 meseca; $p=0,012)$. Univarijantna analiza pokazuje da je 5 ili više CLM prediktor lošijeg DFS (HR 3,989; 95\% CI 1,055 - 15,087; p = 0,042), a odsustvo ekstrahepatatične bolesti je prediktor boljeg OS (HR 0,122; 95\% CI 0,017-0,869; p = 0,036).

Rezultati ovog istraživanja u saglasnosti su sa rezultatima prethodnih velikih studija, koje su za predmet analize imale bolesnike sa operisanim CLM.

Broj CLM i prisustvo ekstrahepatične bolesti prognostički su parametri kod bolesnika sa operisanim CLM, nakon konverzione bio-hemioterapije.

Ključne reči: kolorektalni karcinom, jetra, metastaze, prognoza, hirurgija 